\title{
Overcoming bashfulness: how cocaine aided Freud to summon the courage to meet Charcot
}

\section{Superando a timidez: como a cocaína ajudou Freud reunir coragem para se encontrar com Charcot}

\author{
Hélio A. G. TEIVE ${ }^{1,2}$, Paula T. MARQUES'1 Livia P. de OLIVEIRA'1 Francisco M. B. GERMINIANI', Luciano de \\ PAOLA', Carlos Henrique F. CAMARGO²
}

\begin{abstract}
Jean-Martin Charcot, the most celebrated neurologist of the $19^{\text {th }}$ century, had a profound influence on Sigmund Freud's career. Freud spent the winter of 1885-1886 working in Charcot's neurology department in Paris. During this period, he went to Charcot's house on several occasions to participate in the very famous Tuesday soirées under the guidance of Gilles de la Tourette. Freud was always very proud to be invited and curious to meet the Parisian intellectual elite. On these occasions, however, he was very apprehensive and made frequent use of cocaine. Due to anxiety and the need to appear creative in front of Charcot, it is possible that Freud used cocaine at other times.
\end{abstract}

Keywords: Neurology; cocaine; substance-related disorders

\section{RESUMO}

Jean-Martin Charcot, o neurologista mais célebre do século XIX, teve uma influência profunda na carreira de Sigmund Freud. Freud visitou - Departamento de Neurologia do Hospital Salpêtrière, em Paris, chefiado pelo professor Charcot, durante o inverno de 1885-1886. Durante este período, ele foi várias vezes à casa de Charcot para participar dos famosos saraus de terça-feira, sob a orientação de Gilles de la Tourette. Nessas ocasiões, Freud ficava sempre muito orgulhoso pelo convite, curioso por encontrar a elite intelectual Parisiense, mas também muito apreensivo, e fazia uso frequente de cocaína. Devido à ansiedade e à necessidade de aparentar-se produtivo diante de Charcot, é possivel que Freud tenha usado cocaína outras vezes.

Palavras-chave: Neurologia; coacaína; transtornos relacionados ao uso de substâncias

Sigmund Freud (1856-1939) is known worldwide as the creator of "psychoanalytic theory"1,2 (Figure 1). He was also a neurologist who worked with children with Little's disease and, in 1885, was appointed associate professor in neuropathology ${ }^{3}$. Despite having done important things for medicine, it is mistakenly believed that Freud could have been involved in introducing the use of local anesthesia ${ }^{4}$. Karl Köller was responsible for the discovery of cocaine for local anesthesia ${ }^{5}$. Freud had indicated to his good friend Köller (Coca Köller) that cocaine was a "magical drug".

Freud made personal use of, and indicated cocaine for, his patients and friends ${ }^{4}$. Freud's use of cocaine, when he visited Charcot's house as a select guest at the Tuesday soirées, reveals an important facet of his personality $3,6,7$. The aim of this historical note was to describe the use of cocaine by Freud during his time with Charcot.

\section{FREUD BEFORE CHARCOT}

Freud finished medical school at the University of Vienna in $1882 .{ }^{1,2}$ The following year he joined the neurology service at the University of Vienna, under Theodor Meynert (1833-1892 $)^{1,2,3}$. It is from this period that his first reference to cocaine was expressed in a letter written on April 21, 1884 to his fiancée, Martha Bernays (1861-1951), when he identified it as a "therapeutic project and a hope". In his extensive review article "Über Coca", published in July of 1884, when he

\footnotetext{
${ }^{1}$ Universidade Federal do Paraná, Hospital de Clínicas, Departamento de Medicina Interna, Serviço de Neurologia, Curitiba PR, Brasil; Universidade Federal do Paraná, Departamento de Medicina Interna, Programa de Pós-Graduação em Medicina Interna, Curitiba PR, Brasil. Hélio Afonso Ghizoni Teive (iD) https://orcid.org/0000-0003-2305-1073; Paula Teixeira Marques iD https://orcid.org/0000-0003-1303-9273; Francisco Manoel Branco Germiniani iD https://orcid.org/0000-0001-9494-9759; Luciano de Paola iD https://orcid.org/0000-0002-0512-610X; Carlos Henrique Ferreira Camargo iD https://orcid.org/0000-0002-3533-0347

Correspondence: Hélio A. G. Teive; Rua General Carneiro, 1103/102 - Centro; 80060-150 Curitiba PR, Brasil. E-mail: hagteive@mps.com.br Conflict of interest: There is no conflict of interest to declare.

Received 20 November 2018; Received in final form 15 January 2019; Accepted 14 February 2019.
} 


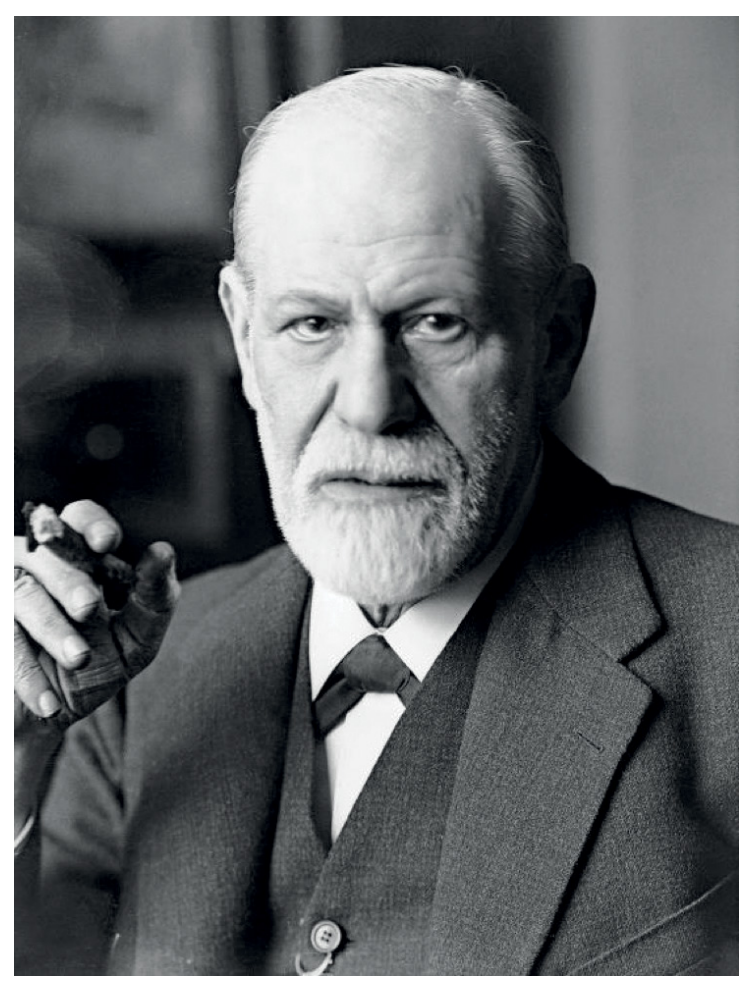

(Extracted from Google Images: From Onico.co, July, 22th, 2017).

Figure 1. Sigmund Freud (1856 - 1939).

was still a resident at the General Hospital of Vienna, Freud described the historical use of cocaine in its countries of origin, the pathophysiological effects of the drug, and its therapeutic actions ${ }^{4,8}$.

\section{CHARCOT'S INFLUENCE ON FREUD}

During the winter of 1885-1886, Freud spent four months (from October 20 to February 28) at the Salpêtrière Hospital in Paris ${ }^{9,10}$. At the first meeting, Charcot inspired a mixture of fascination, reverence and fear in Freud: "At ten o'clock, Mr. Charcot arrives [...], wearing a top hat, with dark, strangely soft eyes (or rather, one is; the other is expressionless and has an inward cast), long wisps of hair stuck behind his ears, clean shaven, very expressive features with full protruding lips - in short, like a worldly priest from whom one expects a ready wit and an appreciation of good living..."11 $\mathrm{He}$ was deeply impressed by Charcot's teachings, and this period proved to be instrumental in opening his mind to new knowledge, expanding his creativity, and shifting his interest from general neurology to hysteria, hypnosis, and other psychological issues ${ }^{1,9,10,11,12,13}$. As he wrote to his future wife shortly after arriving in Paris on November 24, 1885, "I think I'm changing a lot. I will tell you in detail what is affecting me. Charcot, one of the greatest physicians and a man whose common sense borders on genius, is simply wrecking all my aims and opinions. I sometimes come out of his lectures as I would come out of Nôtre Dame, with an entirely new idea of

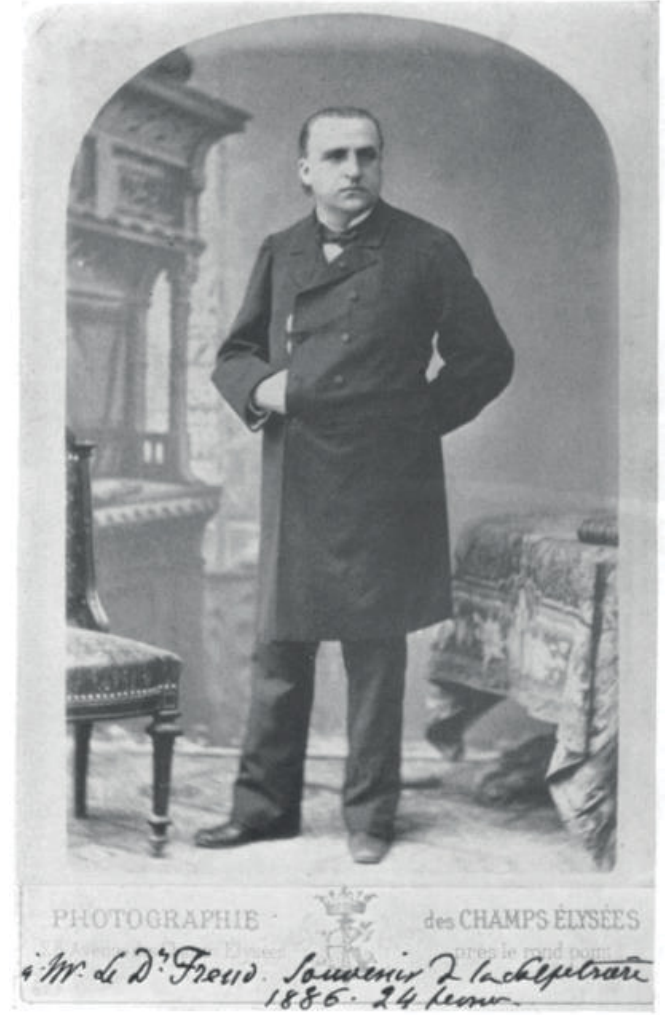

(Extracted from Google Images: From PBS, July, 22th, 2017). Figure 2. Jean-Martin Charcot (1825-1893).

perfection. But he exhausts me; when I come away from him, I no longer have any desire to work at my own silly things. [...] Whether the seed will ever bear any fruit, I don't know; but what I do know is that no other human being has ever affected me in the same way"14.

When Charcot died, on 1893, Freud wrote one of Charcot's most expressive obituaries. He stated "On the $16^{\text {th }}$ of August of this year, [...] the young science of neurology has lost its greatest leader, neurologists of every country have lost their master teacher and France has lost one of her foremost men",7,15.

\section{FREUD AND THE TUESDAY SOIRÉES IN CHARCOT'S HOUSE}

When Freud arrived at Charcot's neurology department at the Salpêtrière hospital, Gilles de la Tourette was the chef de clinique. He received and guided Freud in the hospital and at social events ${ }^{16}$. On January 18, 1886, Freud wrote a letter to his fiancée: "He (Charcot) has invited me, along with Richetti, to visit him at his home tomorrow, Tuesday, after dinner. Many people will be in attendance". "I'm sure you can imagine my apprehension mixed with curiosity and pride. White gloves, white tie, and even a new shirt, a visit to the barber for what little hair I have left. And a little cocaine to loosen my tongue"14. On another occasion, on January 20, 1886, he met Gilles de la Tourette: "We were the first to arrive and had to wait for the diners to leave the dining room. [...] But then the guests arrived 
and we were under fire. Mr. and Mrs. Charcot, Miss Jeanne Charcot, Mr. Léon Charcot (in fact, this was Charcot's son, Jean-Baptiste Charcot), a young Mr. Daudet, son of Alphonse Daudet, Professor Brouardel, a medical examiner with an energetic and intelligent face, Mr. Strauss, Pasteur's assistant and, well known for his work on cholera, Professor Lépine of Lyon, one of the most eminent French clinicians, a sickly little man and an authentic southerner, Mr. Gilles de la Tourette [... $]^{14}$. On February 2, 1886, Freud was once again Charcot's guest: "It was deathly boring and my little dose of cocaine saved me. Ifyou can imagine, this time there were forty or fifty people and I only knew three or four. [... T On Wednesday, February 10, 1886, Freud continued with the description of another evening: "I was once again at length with Charcot himself, from whom I also borrowed a book and one issue of journal [...]. I left with Mr. Gilles de la Tourette, even though it was half past midnight, he invited me into his home to give me a paper he had promised me.[...] I would only have to ask Charcot to be allowed to treat the patients as I see fit. But I am neither courageous nor carefree enough to prolong my stay here."7 On Freud's last day on Charcot's neurology service, Charcot gave him a photograph of himself in a Napoleonic pose, as a souvenir, with a dedication to Freud (Figure 2) (,7 $^{6}$.

\section{CONCLUSION}

Jean-Martin Charcot profoundly influenced Sigmund Freud's career. During his four months in Paris, he visited Charcot, to participate in the very famous Tuesday soirées. Freud was always very proud to be invited to these occasions, but apprehensive and curious before the Parisian intellectual elite, and chiefly concerned with presenting himself properly before his mentor. On these occasions, he made frequent use of cocaine $e^{7,14,15}$. As Freud felt anxiety in the presence of Charcot, in addition to a need to appear more creative in the eyes of his mentor, it is possible that he also used cocaine on other occasions.

\section{References}

1. Goetz CG, Bonduelle M, Gelfand T. Constructing neurology. New York: Oxford University Press; 1995.

2. Gay P. Freud: a life for our time. New York: W. W. Norton; 2006.

3. Bougousslavsky J.Jean-Martin Charcot and his legacy. Front Neurol Neurosci 2014; 35: 44-55.

4. Reis Juniorr A. Sigmund Freud (1856-1939) and Karl Köller (1857-1944) and the discovery of local anesthesia. Rev Bras Anestesiol. 2009 Mar-Apr;59(2):244-57. https://doi.org/10.1590/S0034-70942009000200013

5. Köller C. Personal reminiscences of the first use of cocaine as a local anesthetic in eye surgery. Anesth Analg, 1928;7:9-11.

6. Guinon G. Charcot intime. Paris Medical. 1925;511-6.

7. Souques A. Charcot intime. La Presse Medicale. 1925;42:693-8

8. Freud SS. Über Coca. Secundararzt im k.k. Allgemeinen Kronkenhause in Wien. Centralblatt für die ges. Therapie. 1884 Juli;289-314.

9. Bogousslavsky J. Sigmund Freud's evolution from neurology to psychiatry: Evidence from his La Salpêtrière library. Neurology. 2011 Oct;77(14):1391-4. https://doi.org/10.1212/WNL.0b013e31823152a1
10. Pérez-Rincón H. Pierre Janet, Sigmund Freud and Charcot's psychological and psychiatric legacy. Front Neurol Neurosci. 2011;29:115-24. https://doi.org/10.1159/000321781

11. F.J. Sulloway. Freud: biologist of the mind. London: Burnett Books; 1979.

12. Lepoutre T, Villa F. Freud with Charcot: Freud's discovery and the question of diagnosis. Int J Psychoanal 2015 Apr;96(2):345-68. https://doi.org/10.1111/1745-8315.12247

13. Miller JA, Sabshin M, Gedo JE, Pollock GH, Sadow L, Schlessinger N. Some aspects of Charcot's influence on Freud. J Am Psycoanal Assoc 1969 Apr;17(2): 608-23. https://doi.org/10.1177/000306516901700215

14. Freud S. Letter to Martha Bernays 86 (Paris, November 24, 1886). In: Freud EL. Letters of Sigmund Freud: 1856-1939. New York: Dover; 1914.

15. Gelfand T. "Mon cher docteur Freud": Charcot unpublished correspondence to Freud, 1888-1893. Bull Hist Med. 1988;62(4):563-88.

16. Walusinski O. Gilles de la Tourette: education, medical studies, medical practice. London: Oxford University Press; 2018. 